研究

鉄合金のプラズマ処理-（II）オーステナイト系鉄合金 (Fe-18Cr-9Ni) のプラズマ窒化 桑原 秀行社, 高田 潤社

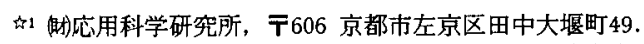

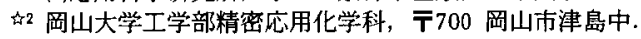

\title{
Plasma Processing of Iron Alloys-(II) Plasma Nitriding of an Austenitic Iron (Fe-18Cr-9Ni) Alloy
}

\author{
Hideyuki Kuwahara ${ }^{\hat{\gamma} 1}$ and Jun Takada $\hat{w}^{2}$ \\ th Research Institute for Applied Sciences, Tanaka Ohicho Sakyo-ku, Kyoto 606. \\ \&2 Faculty of Applied Fine Chemical, Department of Engineering, Okayama University, Tsushima-naka, \\ Okayama 700 .
}

Received December 12, 1991

To discuss plasma nitriding process as a kind of preparing process of functional gradient material, various characteristics of the layers nitrided by plasma of a mixed gas of nitrogen and hydrogen were studied. Fe-18Cr-9Ni alloy was nitrided at the range of temperature from 723 to $823 \mathrm{~K}$ for various periods $(3.6 \mathrm{ks}$ to $108 \mathrm{ks}$ ), and then each specimen was immediately quenched into iced water. Microstructural observation, $x$-ray diffraction examination, measurement of hardness, EPMA analysis of nitrogen, chronium, nickel, and iron, and chemical analysis of the surface layer of sepcimen were conducted. TEM observation of extracted CrN particles was also carried out to determine their mean diameter. The main results are as the follows: (1) The plasma nitriding is available for preparing FGM. (2) The profile of dissolved nitrogen in the nitriding layer, in which $\mathrm{CrN}$ was precipitated, decreased continueously from the specimen surface to the nitriding front. (3) The nitrogen is dissolved to $1.73 \mathrm{wt} / \mathrm{t}$ $823 \mathrm{~K}$. This nitrogen content is equal to about 10 times of the reported values. (4) The mean size of the $\mathrm{CrN}$ particle is $7 \mathrm{~nm}$ in diameter.

\section{1 緒 言}

傾斜機能材料の多くは，粉末法，CVD，PVD， メッキ，溶射法などによって研究が進められている。 いずれの方法も得られる性質の連晩的㑯斜化を実現 するために，精力的な研究が行なわれている゙”。こ れに対して，㹡散法による裳能傾斜材料の作製は，
性筫の連䌇的変化を容易に得ることができる。例え は，窒素を試料表面から侵入・固溶・拡敢させる空 化法である。従来，窒化は， $\mathrm{NH}_{3}$ ガス気流中で試料 を加熱して行なわれてきたが，近年， $\mathrm{N}_{2}$ と $\mathrm{H}_{2}$ の 混合ガスをグロー放電によってプラスマ化して窨化 反店を進めるプラスマ窒化法が工業的に広く用いら 
れるようになつた。著者らは，鉄合金のプラスマ窒 化による反応機構や強化機檕傅につて系統的に研究 した ${ }^{2-6)}$ 。これらの研究において, $\mathrm{NH}_{3}$ ガスによる 高 $\mathrm{Cr}$ 鉄合金の窒化が表面酸化被膜のために困難で あるのに対しで', プラズマ窒化はこれを極めて容 易に窒化できることを示した21。

本研究は, $\mathrm{Fe}-18 \mathrm{Cr}-9 \mathrm{Ni}$ 鉄合金をプラスマ窒化 して, 傾斜機能材料作製法としてのプラズマ窒化法 の有効性を検討する。

\section{II 試料および実験方法}

ステンレス製の真空槽の中にヒーターを配置した 装置に, $\mathrm{N}_{2}$ (=0.5 1.3 Torr) と $\mathrm{H}_{2}(=1.5 \sim$

3.7 Torr）を導入し, 直流グロー放電によってプラ スマ化して $\mathrm{Fe}-18 \mathrm{Cr}-9 \mathrm{Ni}$ 合金をプラズマ窒化し た。窒化は, 723, 773, $823 \mathrm{~K}$ においてそれぞれ $3.6,18,2.4,108 \mathrm{ks}$ 行い, プラズマ窒化後, 直 ちに氷水中で試料を冷却した。なお, 昇温中は $\mathrm{H}_{2}$ のみを導入した。試料断面において, 光学頙微鏡に よる組織覞察，微小硬さ测定（測定荷重；100 g, 荷重時間；30 s），EPMA（日立，X-650）による濃 度分析，及び円柱状試料をプラズマ窒化して，試料 表面層を旋盤で刿り, 切粉を化学分析した。更に, 試料表面から抽出レプリカ法によって析出物を採取 して, TEM 锶察を行なつた。

\section{III 実験結果および考察}

\section{1 組織钼察}

823 K で 43.2 ks プラズマ窒化した試料断面の

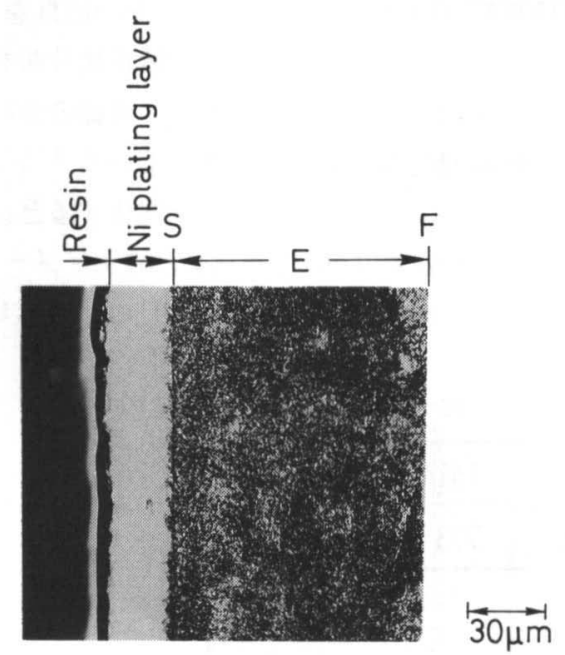

Fig.1 Typical microstructure of $\mathrm{Fe}-18 \mathrm{Cr}-9 \mathrm{Ni}$ alloy nitrided at $823 \mathrm{~K}$ for $43.2 \mathrm{ks}$.
組織を Fig.1 に示す。窒化層先端 $\mathrm{F}$ は試料表面 S に平行に成長していることが判る。また，試料表 面に外部窒化層は形成されていない。同じ試料の $\mathrm{NH}_{3}$ ガス窒化 ${ }^{31}$ や低婊度のフェライト系鉄合金のプ ラスマ窒化 ${ }^{4-5)}$ では試料表面に外部窒化層を形成す るのと対照的である。これは以下の理由によると考 えられる。試料表面で鉄窒化物が形成されても,プ ラズマ中のイオンの衙突によって鉄窒化物がスパッ タされるために, 試料表面では鉄窒化物が成長しな いからである ${ }^{6)}$ 。従つて, $\mathrm{Fe}-18 \mathrm{Cr}-9 \mathrm{Ni}$ 合金のプ ラズマ窒化では, プラズマと合金とが直接反応する。 3.2 硬さ分布

試料断面における硬さ测定結果の一例を Fig.2 に示す。試料表面から窒化層先端までほぼ定の硬 さを示していることから，窒化層中には均質な窒化 物の析出が予剆される。本合金の $\mathrm{NH}_{3}$ ガス窒化に よる硬さは表面で約 HV=1100 であり, 試料表面か ら内部に向かって低下している31。なお, 試料表面 から窒化層先端までの距離と Fig.1 に示した窒化 層の厚さとは一致する。

\section{3 E PMA}

試料表面から窒化層中の $\mathrm{N}, \mathrm{Ni}, \mathrm{Cr}$, 及び $\mathrm{Fe}$ 賑 度を EPMA によって分析した結果を Fig.3 に示す。 窒素濃度は, 窒化層中ではほほ一定の濃度を示し， 窒化層先端において急激に低下していることが判る。 組織, 断面硬さ及び EPMA から求められる窒化層の 厚さはほぼ致している。

窒化層の厚さの 2 乗と窒化時間 $\mathrm{t}$ とは比例し, $\mathrm{E}^{2}=\mathrm{K}_{\mathrm{p}} \mathrm{t}$

と表わされる。比例係数 $\mathrm{Kp}$ は窒化層の成長速度定

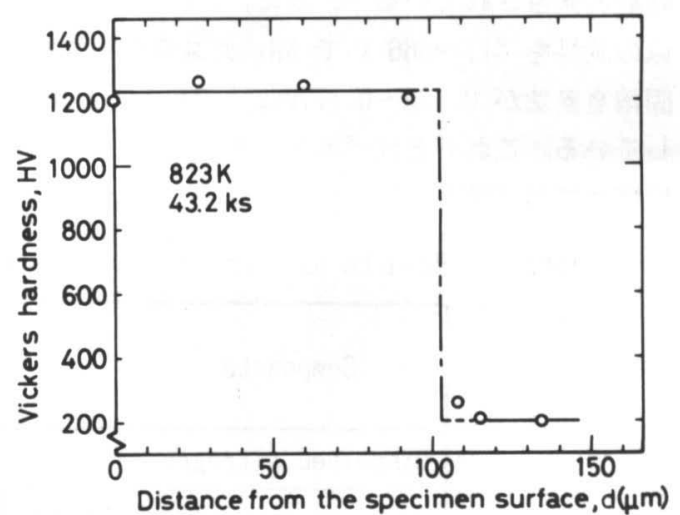

Fig.2 A profile of hardness of $\mathrm{Fe}-18 \mathrm{Cr}-9 \mathrm{Ni}$ alloy nitrided at $823 \mathrm{~K}$ for $43.2 \mathrm{ks}$. 


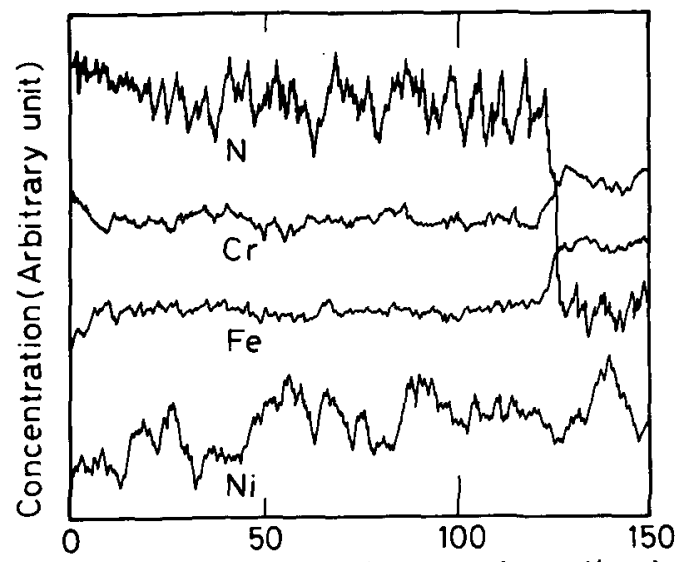

Distance from the specimen surface, $d(\mu \mathrm{m})$

Fig. 3 Concentration profiles of $\mathrm{N}, \mathrm{Cr}, \mathrm{Ni}$, and $\mathrm{Fe}$ on the cross section of $\mathrm{Fe}-18 \mathrm{Cr}$ $9 \mathrm{Ni}$ alloy nitrided at $823 \mathrm{~K}$ for $108 \mathrm{ks}$.

数を意味している。各プラススマ窒化温度における KP を求め, その温度依存性を求めると,

$K_{p}=1.15 \times 10^{-5} \exp \left(-\frac{121 \mathrm{~kJ} / \text { mol }}{R T}\right)$

となる。これより，本プラズマ窒化法により佰斜機 能化した窒化層の成長を制御することが可能となる。 3.4 化学分析

試料表面から約 $0.5 \mu \mathrm{m}$ の層を剬り採り，固溶 窒素及び CrN となつた窒素とに分嚾して化学分析 した結果を Table 1 に示す。本合金に固溶してい る窒素量は, $723 \mathrm{~K}$ で 1.37wt\&, $823 \mathrm{~K}$ で, 1.73 wt\%である。 $\mathrm{Fe}-\mathrm{Ni}-\mathrm{Cr}-\mathrm{N}$ 系の平衔状驡图に関す る研究から, 873 K における固溶窒素浱度は 0.1 wt\% と報告されている7”。また，Cox とEckel は類 似の試料を 811〜866 K で $\mathrm{NH}_{3}$ ガス窒化した場合， 固溶穻素量が 0.125〜0.177wt积)であることを報告 している。これらと比べと，本研究の固溶窒素量 は且めて高い值を示している。プラスマ窒化ては，
合金試料表面に铁窒化物を形成しても直ちにスパッ タされて試料表面て鉃窑化物が成長せず，窒化中常 にプラスマと合金との直接反応が生じるために，プ ラスマ中の程々の活性種が反底して，量の空素が 合金中へ固溶したものと考えられる。

\section{3. $5 \mathrm{X}$ 線回折}

試料表面及び窒化層内部の試料表面に平行な面で X 線回折を行なった結果，窒化層は，試料表面から 窒化層先端までオーステナイト（以下，y）相と CrN の二相で権成されている。試料表面での X 線 回折結果を Fig.4 に示す。同定された $\gamma$ 相の大き さと試料表面からの検出位置との関你を Fig.5 に 示す。窒化層中の $\gamma$ 相の格子定数は窒化前の $\gamma$ 相の 格子定数よりも大きく，陚料表面から内部に入るほ ど格子定数は小さくなることが判る。窒素原子の 相中への侵入量が多いほど， $\gamma$ 相の格子定数が大き くなることが知られている

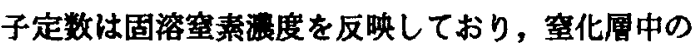
固溶空素量が試料表面から空化層先端までプラスマ 窰化によって連続的に変化することを示している。

また,Fig.4 に示すように，窒化層中では析出物 CrN が碝細に分散析出するので，高い硬さ（Fig.2 参照）を示す。従って，優れた耐器性性を有する㑯 科機能材料となることが期待される。

3. 6 TEM垷察

$\mathrm{Fe}-18 \mathrm{C} r-9 \mathrm{Ni}$ 合金をプラス゚窒化すると公化風 全域に亘り，CrN 粒子を析出することが判つた。こ の CrN の大きさを調べるために，試料表面功 $\mathrm{CrN}$ を抽出し TEM 闚察を行なつた。その結果を Fig.6 に示す。CrN の大きさは，対数正规分布を示 し，平均粒怪は $7 \mathrm{~nm}$ と求められた。同様の分布が 高田らの内部酸化の研究で報告されている10)。即 ち, $\mathrm{Fe}-18 \mathrm{Cr}-9 \mathrm{Ni}$ 合金をプラズマ窒化すると,ナ ノメータ极の析出物 CrN と母相 $\gamma$ とのナノメータ ーコンポッジトの窒化層を形成し，且つ，固溶窒素

Table 1 Results of chemical analysis of surface layer of specimens plasma-nitrided.

\begin{tabular}{|l|c|c|c|}
\hline \multirow{2}{*}{ Componets } & \multicolumn{3}{|c|}{ Plasma nitriding temperature } \\
\cline { 2 - 4 } & $723 \mathrm{~K}$ & $773 \mathrm{~K}$ & $823 \mathrm{~K}$ \\
\hline Dissolved nitrogen content (wtX) & 1.37 & 1.55 & 1.73 \\
\hline Cr content as presented CrN (wtX) & 15.52 & 15.96 & 16.40 \\
\hline Dissolved chromium content (wtX) & 2.48 & 2.04 & 1.60 \\
\hline
\end{tabular}


量を試料表面から試料内部へ㑯科化した材料を作製 することができる。

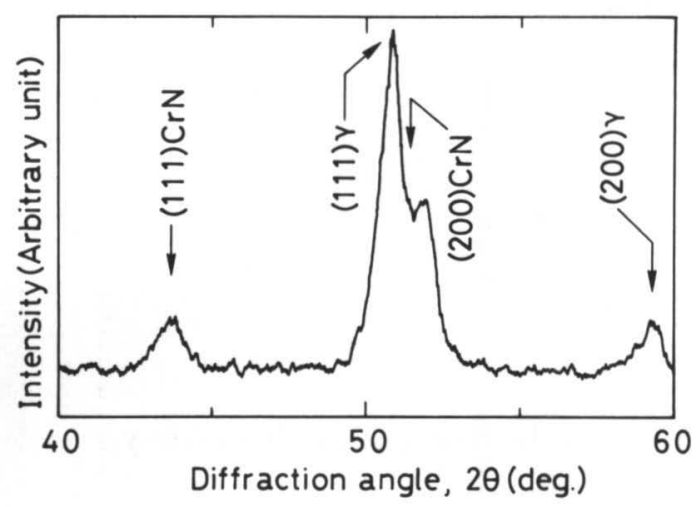

Fig.4 An $x$-ray diffraction pattern of $\mathrm{Fe}$ $18 \mathrm{Cr}-9 \mathrm{Ni}$ alloy nitrided at $823 \mathrm{~K}$ for $108 \mathrm{ks}$.

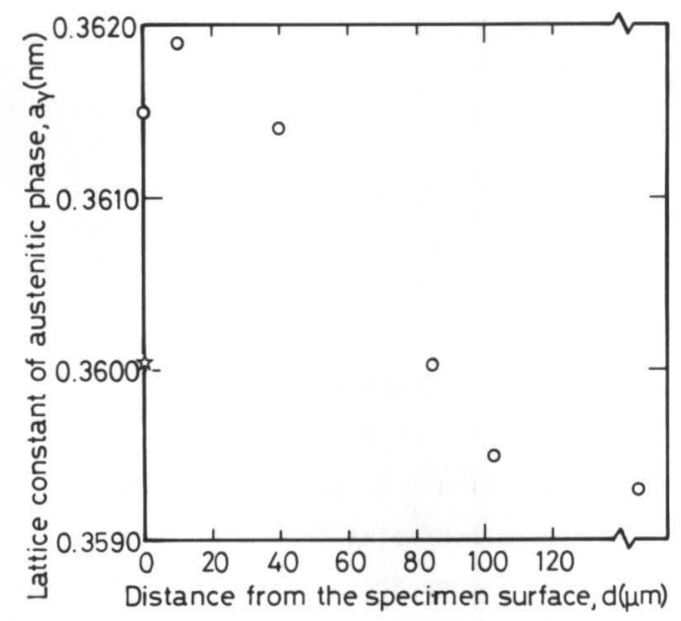

Fig.5 Relationship between the lattice constant of austenite phase nitrided at $823 \mathrm{~K}$ and the distance from the specimen surafce.

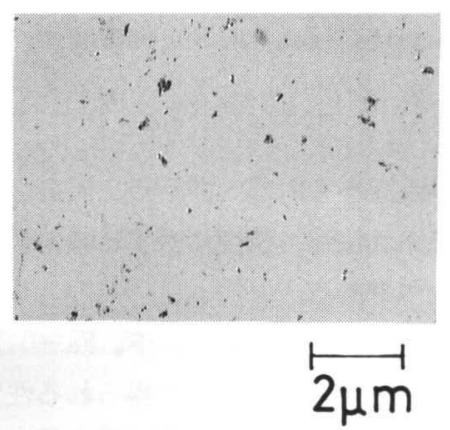

Fig.6 Bright field image of extracted $\mathrm{CrN}$ particles.

\section{IV ま と め}

$\mathrm{Fe}-18 \mathrm{Cr}-9 \mathrm{Ni}$ 合金を $\mathrm{N}_{2}$ と $\mathrm{H}_{2}$ 混合ガスを用い て 723〜823 K で 3.6〜108 ks プラズマ窒化し, 傾科機能材料作製方法としてのプラズマ窒化法を検 討した。以下の結論を得てプラスマ窒化法が侕鈄機 能材料の作製法として有効であることを示した。

（1）オーステナイト中の固溶空素量を飛䠰的に増加 させることができた。

（2）試料表面から窒化層先端まで一種類の窒化物 $\mathrm{CrN}$ を析出した窒化層を形成した。

（3）固溶窒素濃度は, $7 \mathrm{~nm}$ 程度の $\mathrm{CrN}$ と窒素を固 溶した母相 $\gamma$ から成るナノメーターコンポジッ トである窒化層中を試料表面から内部に向かつ て徐々に減少する。

\section{賭辟}

EPMA 分析, X 線回折, 及び化学分析をして下さ いました京都大学工学部技官 畦崎義輝氏, 同木村 訓氏，及び同（当時）北村辰夫氏に感謝致します。

\section{文献}

1. 例元ば, 粉体粉末冶金協会平成 3 年度秋季大 会講演概要集，(1991)，32-43.

2. H.Kuwahara, J.Takada, and I.Tamura: Pro. of ISPC-7th, Eindhoven. (1985) 474 .

3. H.Kuwahara, H.Matsuoka, J.Takada, Y.Tomii, S.Kikuchi, and T.Takayama: J.Materials Sci.,25(1990) 4120.

4. J.Takada, Y.Oizumi, H.Miyamura, H.Kuwahra, S.Kikuchi: 0xidation of Metals,26(1986) 19

5. 高田 潤, 松本宏之, 桑原秀行: 粉体粉末冶金 協会平成 3 年度秋季大会講演概要集, (1991) 44

6. H.Kuwahara, H.Matsuoka, J.Takada, S.Kikuchi, Y.Tomii, and I.Tamura: Oxidation of Metals,36(1991)143.

7. 增本 健, 今井勇之進:日本金属学会誌, 33(1969) 1364 .

8. J.F.Eckel and T.B.Cox: J.Materials, $3(1968) 605$.

9. 土屋正行，泉山昌夫，今井勇之進：日本金属学 会誌, 29(1956) 427 .

10. J.Takada, S.Miyawaki, K.Kamata, and M.Adachi: Trans.JIM., 25(1984)784. 